Acta vet. scand. 1968, 9, 223-241.

From the Department of Biochemistry, University of Århus, Denmark.

\title{
ON THE NORMAL ACTIVITIES \\ OF GLUCOSE-6-PHOSPHATE DEHYDROGENASE \\ AND 6-PHOSPHO-GLUCONATE \\ DEHYDROGENASE IN BOVINE ERYTHROCYTES
}

\author{
By \\ Jens Steensgaard
}

Investigations on the glucose-6-phosphate dehydrogenase $\left(\mathrm{G} \mathrm{PD}^{\star}\right)$ and 6-phospho-gluconate dehydrogenase activities (6PGD) in the erythrocyte have attracted great interest in the last decade, especially as it has been shown that a congenital low activity of G6PD in human erythrocytes can cause a nonspherocytic hemolytic anemia $(2,5,15)$, and also because it has been shown that the intravital decrease in G6PD activity plays an important role in determining the life span of the erythrocyte (17, 18). Only a few studies on the activities of G6PD and 6PGD in bovine erythrocytes have been performed $(4,21,22)$, and these investigations have been carried out on relatively small groups of animals and with different techniques, so that comparison between the results of the different authors has not been possible.

This work reports some investigations on the normal activities of G6PD and 6PGD in bovine erythrocytes from the breeds RDM, SDM and Danish Jersey. A significant difference between the mean activities of 6PGD in the erythrocytes of RDM and SDM is demonstrated. It is further shown that the G6PD activity in the

* Abbreviations used are as follows: G6PD = glucose-6-phosphate dehydrogenase (D-glucose-6-phosphate: NADP oxidoreductase, E.C. 1.1.1.49), 6PGD = 6-phospho-gluconate dehydrogenase (6-phospho-Dgluconate: NAPD oxidoreductase, E.C. 1.1.1.44), G6P = D-glucose-6phosphate, 6PG $=6$-phospho-D-gluconate, NADP $=$ nicotinamide adenine dinucleotide phosphate, $\mathrm{PCV}=$ packed cell volume $\mathrm{MCHC}=$ mean corpuscular hemoglobin concentration, $\mathrm{Hb} \%=$ hemoglobin concentration, $\mathrm{RDM}=$ red Danish milk breed and SDM $=$ black and white Danish milk breed. 
fetus is much higher than in mature cattle, and that the high G6PD activity decreases to the level normal for older animals in approximately 6 weeks. The 6PGD activity in fetal bovine erythrocytes is only slightly higher than in adult bovine erythrocytes.

\section{MATERIAL}

The material comprises 157 cows, bulls and calves older than 3 months, 16 newborn calves and 29 fetuses, giving a total of 202 animals. Among the 157 animals older than 3 months 80 were RDM, 46 SDM and 31 Jersey. The average age of these animals was as follows: RDM 38 months, SDM 40 months and Jersey 41 months. The newborn calves were all RDM. Among the 29 fetuses 18 were RDM, 9 SDM and 2 Jersey. The race of the fetuses is given according to their maternal breed. The blood samples were all taken from normal, well-fed animals. The blood samples were collected partly by venous puncture of farm animals in the neighbourhood of Århus, and partly by collecting blood during the bleeding of newly slaughtered animals at the public slaughterhouse of Århus. The blood samples from fetuses were collected by C. J. Jensen, the chief veterinarian at the public slaughterhouse in Århus.

The age and milk yield of the animals are given according to the owner's statements. The age of the slaughterhouse animals was assessed from the development of the teeth and body. The inaccuracy of these estimations is believed to be within $10 \%$.

The blood samples were collected in $10 \mathrm{ml}$ centrifuge tubes containing $38 \mathrm{mg}$ trisodium-citrate-2-hydrate and $50 \mathrm{mg}$ glucose in order to increase the stability. Immediately after collection, the blood samples were cooled to approximately $4^{\circ} \mathrm{C}$ in an icebath or a refrigerator. The plasma $\mathrm{pH}$ in blood samples thus collected was 7.4-7.5; and the blood samples proved stable with respect to G6PD and 6PGD activities for at least a week. The blood samples from the first 14 newborn calves were, however, collected in $10 \mathrm{ml}$ centrifuge tubes containing $100 \mu \mathrm{l}$ of a $2 \%$ solution of heparin. The heparinized blood samples showed the same G6PD and 6PGD activities as those collected in the mentioned citrateglucose mixture.

The stability of the blood samples containing heparin is stated to be lower than that of blood samples collected in citrate-glucose (26), but the present investigations showed no alteration of the G6PD and 6PGD activities within the first $12 \mathrm{hrs}$. In the samples 
collected in heparin, the determinations of G6PD and 6PGD activities were initiated within two hrs. of bleeding. The activities of the enzymes in the blood collected in citrate-glucose were determined within 12 hrs. of collection.

\section{METHODS}

The activities of G6PD and 6PGD were estimated by a modification of the method of Glock \& McLean (8). The activity of 6PGD was determined by recording the increase in optical density at $340 \mathrm{~nm}$ in a "standard" reaction cell containing hemolysate, 6PG, NADP, $\mathrm{Mg}^{++}$and buffer. G6PD activity was determined as the difference between the activity in a "standard" reaction cell containing in addition G6P; and the 6PGD activity measured as described for the "standard" cell above. In the assay the same concentration of reagents, same $\mathrm{pH}$ and same temperature as recommended by Bishop (3) were used.

The erythrocytes in the blood samples were first washed twice in a $0.9 \%$ solution of sodium chloride with centrifugation $10 \mathrm{~min}$. at $1200 \times \mathrm{g}$ between each wash. After the last centrifugation the supernatant was removed, and the red cells resuspended in an equal volume of saline. $50 \mu \mathrm{l}$ of the erythrocyte suspension were hemolyzed in a test tube containing $5 \mathrm{ml}$ of $0.01 \%$ solution of saponin in water. Duplicate $1 \mathrm{ml}$ samples of the hemolysate were pipetted in two OS cells containing both $1.5 \mathrm{ml}$ tris buffer (170 $\mathrm{mM}$, pH $7.5\left(37^{\circ} \mathrm{C}\right.$ ) and $20 \mathrm{mM} \mathrm{MgCl}_{2}$ ) and $0.4 \mathrm{ml}$ NADP (1.5 $\mathrm{mM}$ ). The first cell contained in addition $0.1 \mathrm{ml}$ substrate 1 (18 mM G6P + 18 mM 6PG), and the second cell (the "standard" cell) contained $0.1 \mathrm{ml}$ substrate 2 (18 mM 6PG). Hemolysate, reagents and cells were all heated to $37^{\circ} \mathrm{C}$ before initiating the reaction. After mixing, the absorbance at $340 \mathrm{~nm}$ was read against a blank containing $1.0 \mathrm{ml}$ hemolysate and $2.0 \mathrm{ml}$ tris buffer. A Zeiss PMQ II spectrophotometer, thermostated at $37^{\circ} \mathrm{C}$ was used.

According to Bishop (3) the activities were calculated from the increase in optical density per min. at $340 \mathrm{~nm}\left(\Delta \mathrm{E}_{340}\right)$. One unit of enzyme activity is the amount of enzyme which can reduce $1 \mu$ mole NADP per min. under the described experimental conditions. Calculations were made using the following expression:

$\frac{\left(\Delta \mathrm{E}_{340} / \mathrm{min} .\right) \cdot 10^{5}}{9.9 \cdot 2.073 \cdot\left(\mathrm{PCV} \cdot 10^{-2}\right)}=$ number of units per $100 \mathrm{ml} \mathrm{PCV}$

In the formula $10^{5}$ is a conversion factor from $1 \mu \mathrm{l}$ to $100 \mathrm{ml}, 9.9$ 
is the measured volume in $\mu \mathrm{l}$, and 2.073 is the absorbance of $1 \mu$ mole $\mathrm{NADPH}_{2}$ in $3 \mathrm{ml}$ solution at $340 \mathrm{~nm}$ and a lightpath of $1 \mathrm{~cm}(7)$.

The packed cell volume was determined in adjusted Hamburger hematocrit tubes. The tubes were centrifuged $45 \mathrm{~min}$. at $1200 \times \mathrm{g}$ which gives a complete packing of washed bovine red cells.

The described technique resulted in a constant increase in optical density per min. for the first 16-20 min. This method allowed measurement of G6PD and 6PGD activities between approximately 20 and 800 units per $100 \mathrm{ml} \mathrm{PCV}$ in erythrocyte suspension with a packed cell volume near $40 \%$. Fig. 1 shows that there is an inverse proportionality between the degree of dilution and the activities of G6PD and 6PGD in the same erythrocyte suspension.

The hemoglobin concentrations in erythrocyte suspensions were assayed as methemoglobin cyanide according to I.C.S.H. (12). The calculation of the hemoglobin concentration was based on the molecular weight of human hemoglobin (64458). MCHC was calculated as $\mathrm{Hb} \% / \mathrm{PCV} \times 100$. The glucose concentration of

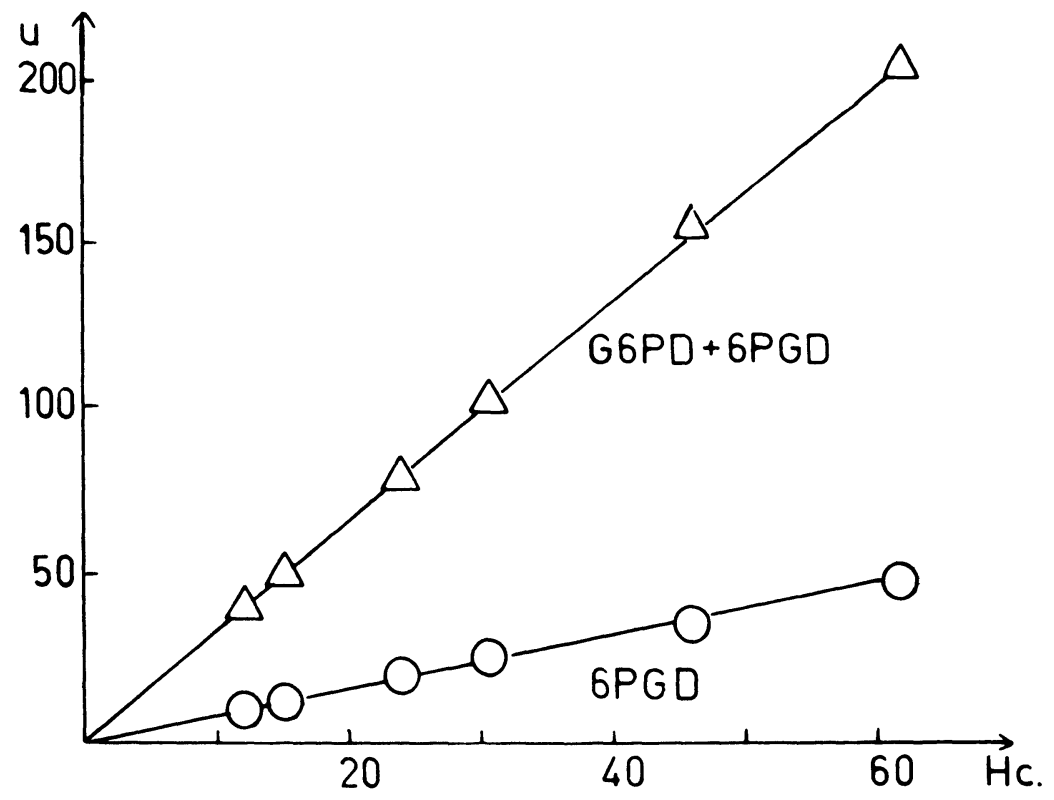

Figure 1. The figure shows the measured activities of G6PD and 6PGD in relation to the packed cell volume $(\mathrm{Hc})$ in a series of dilutions of the same erythrocyte suspension. 
whole blood was measured by the method of Nelson and Somogyi $(19,23,24)$.

\section{Statistical methods}

Kolmogorov-Smirnov test $(11,25)$. The empirical distribution function is drawn in a diagram which contains the normal cumulative distribution function with confidence bands (cf. Figs. 2-7). In the diagram $(x-\bar{x}) / s$ is the abscissa, where $x$ denotes the observed value, $\bar{x}$ the mean and $s$ the estimated standard deviation of a population, while the ordinate is the ordinate to the normal distribution function $F(x)=\int_{-\infty}^{x}(1 /(s(2 \pi) 0.5))(\exp (-0.5((x-\bar{x}) / s) 2)) d x . F(x)$ is calculated as an approximated expression, because the equation $\mathrm{F}=$ $0.5+0.5 \cdot(\operatorname{sign} z)\left(1-1 /\left(\left(\left(\left(\left(0_{0.00000538} \mathrm{~T}+0.00004889\right) \mathrm{T}+\right.\right.\right.\right.\right.$ $\left.0.000038) \mathrm{T}+0.00327763) \mathrm{T}+0.021141) \mathrm{T}+0.04986736) \mathrm{T}+1)^{16}\right)$ gives a graphical picture identical with $F(x)(9)$, when $T=|z|$, where $\mathrm{z}$ denotes values on the abscissa between - 2.5 and 2.5. The confidence bands are calculated as $\left(\mathrm{F}+\mathrm{d}_{i \ell}(\mathrm{N})\right)$ and $\left(\mathrm{F}-\mathrm{d}_{\alpha q}(\mathrm{~N})\right)$, where $\mathrm{d}_{\alpha \kappa}(\mathrm{N})$ is a tabulated value depending on the number of observations $(\mathrm{N})$ and the level of significance chosen $(\alpha)$. In Figs. $2-7$ the inner confidence bands are drawn for $\alpha=0.05$, the outer for $\alpha=0.01$. The empirical distribution function $S_{N}(x)$, is drawn as a step function with $N$ steps. If $S_{N}(x)$ passes the confidence bands, the zero hypothesis, $S_{N}(x)$ belongs to $F(x)$, cannot be accepted at the level of significance chosen.

$\chi^{2}$ test for independency (11). The paired values of two distributions are sorted in a 2 times 2 contingency table with the means of the two distributions as dividing lines. If $a, b, c$ and $d$ denote the number of values in the respective cells, we have $x^{2}=(a+b+c+d) x$ $(a d-b c)^{2} /((a+b)(c+d)(b+d)(a+c))$. The number of degrees of freedom is 1 , and the limits of significance for $P=0.05$ and $P=0.01$ are 3.841 and 6.635 respectively.

Regression analysis. The coefficient of correlation is obtained from the expression (6) $r=(n \Sigma x y-\Sigma x \Sigma y) /\left(\left(n \Sigma x^{2}-(\Sigma x)^{2}\right)\left(n \Sigma y^{2}-\right.\right.$ $\left.\left.(\Sigma y)^{2}\right)\right)^{0.5}$ and the coefficient of regression from $b=(n \Sigma x y-\Sigma x \Sigma y) /$ $\left(n \Sigma x^{2}-(\Sigma x)^{2}\right)(17)$. The hypothesis, $r=0$, is tested by a t-test, where $t=r\left((n-2) /\left(1-r^{2}\right)\right) 0.5$ and the number of degrees of freedom $(v)$ are $\mathrm{n}-2$. The hypothesis that the true coefficient of regression is zero is similarly tested by a t-test, where $t=b\left((n-2)\left(\Sigma(x-\bar{x})^{2}\right) / \Sigma\left(y-y^{\prime}\right)^{2}\right)^{0.5}$ and $v=\mathbf{n}-\mathbf{2}$.

F-test. The variances of two normal distributions can be compared by an F-test, where $F=\mathrm{s}_{1}{ }^{2} / \mathrm{s}_{2}{ }^{2} . \mathrm{s}$ is the estimated standard deviation of a population, calculated from the expression $s=\left(\left(\Sigma x^{2} /(n-1)\right)\right.$ $\left.-\left((\Sigma x)^{2} /\left(n^{2}-n\right)\right)\right)^{0.5}$. (6).

t-test. The means of two normal distributions whose variances according to the F-test are significantly different can be compared in the following way: $t=(\bar{x}-\bar{y}) /\left(\left(s_{1}{ }^{2} / n_{1}\right)+\left(s_{2}{ }^{2} / n_{2}\right)\right) 0.5$. The number of degrees of freedom is given by $v=\left(\left(\left(\mathrm{s}_{1}{ }^{2} / \mathrm{n}_{1}\right)+\left(\mathrm{s}_{2}{ }^{2} / \mathrm{n}_{2}\right)\right)^{2} /\left(\left(\left(\mathrm{s}_{1}{ }^{2} / \mathrm{n}_{1}\right)^{2}\right.\right.\right.$ $\left.\left.\left./\left(\mathrm{n}_{1}+1\right)\right)+\left(\left(\mathrm{s}_{2}{ }^{2} / \mathrm{n}_{2}\right)^{2} /\left(\mathrm{n}_{2}+1\right)\right)\right)\right)-2 .(11)$. 


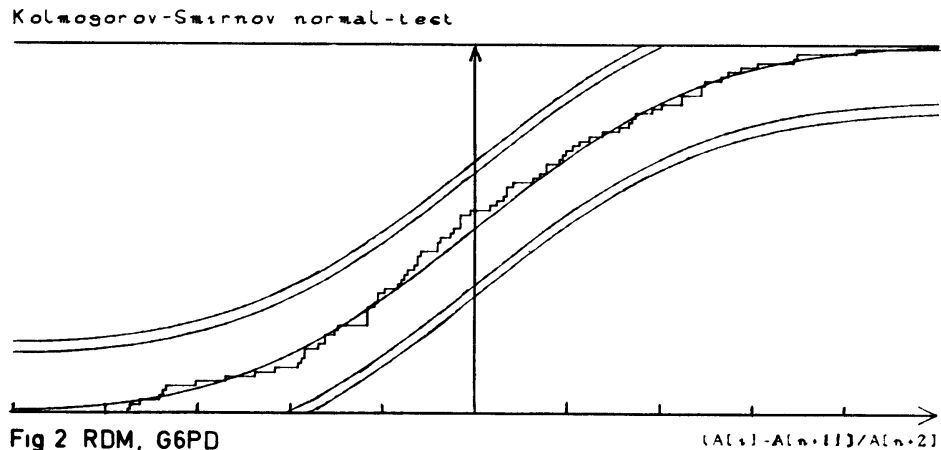

Kolmogorov-Swirnov normal-tect

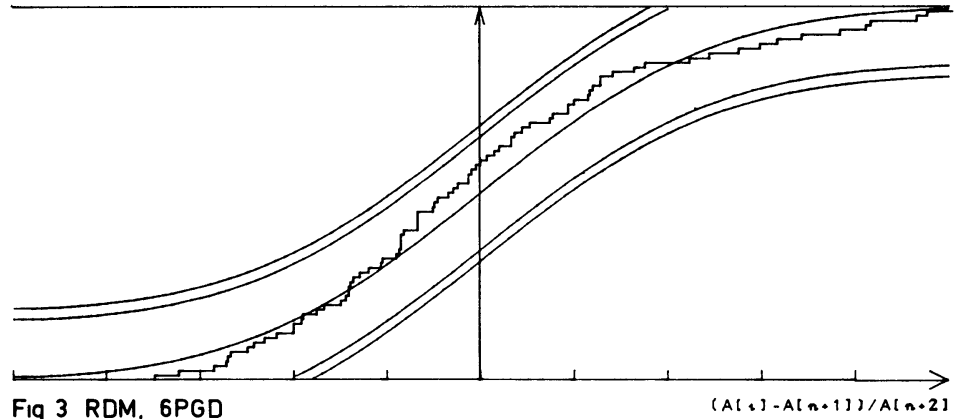

Fig 3 RDM, 6PGD

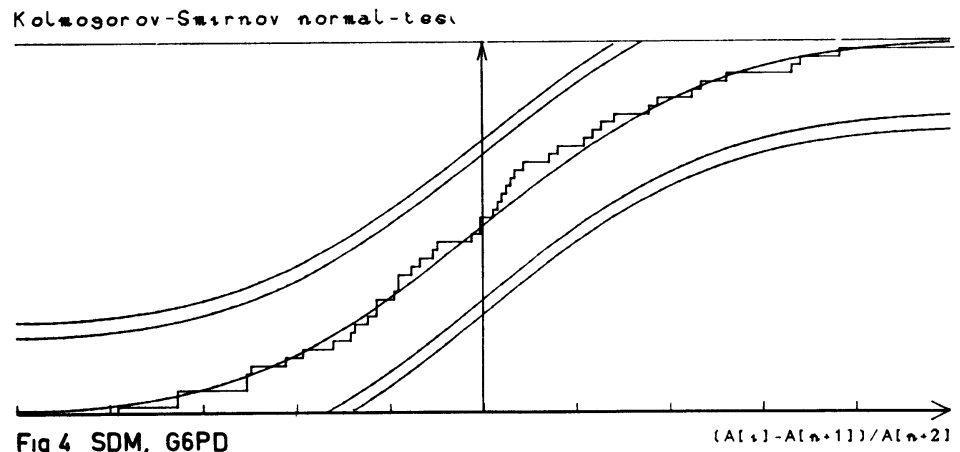

F i g u r e 2-7. Kolmogorov-Smirnov test of the distributions of the activities of G6PD and 6PGD in the erythrocytes of cattle of RDM, SDM and Jerseys breeds. The curves are drawn by a Gier Computer. The designation of the abscissa is the computer code for $(x-\bar{x}) / s$. A more explicite explanation of the diagrams is given under statistical methods. Notice that the empirical distribution functions in no case pass the confidence bands. 
Kolmogorov-Smirnov normal-tect

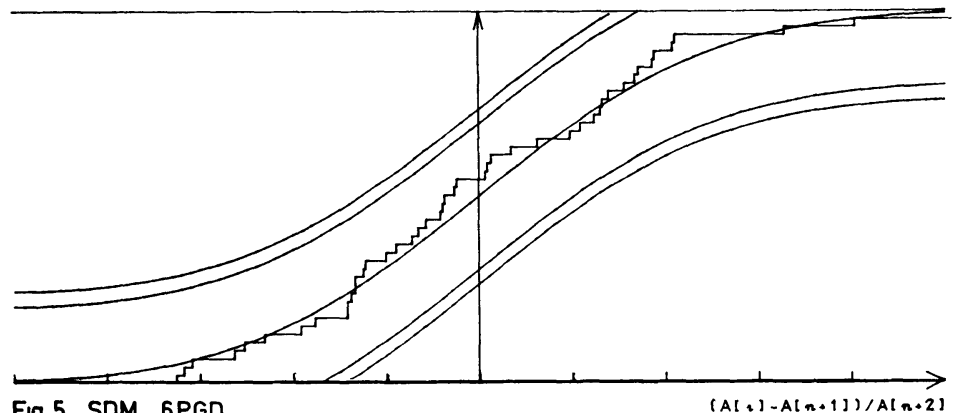

Fig 5 SDM, 6PGD

$(A[1]-A(n+1)) / A(n+2)$

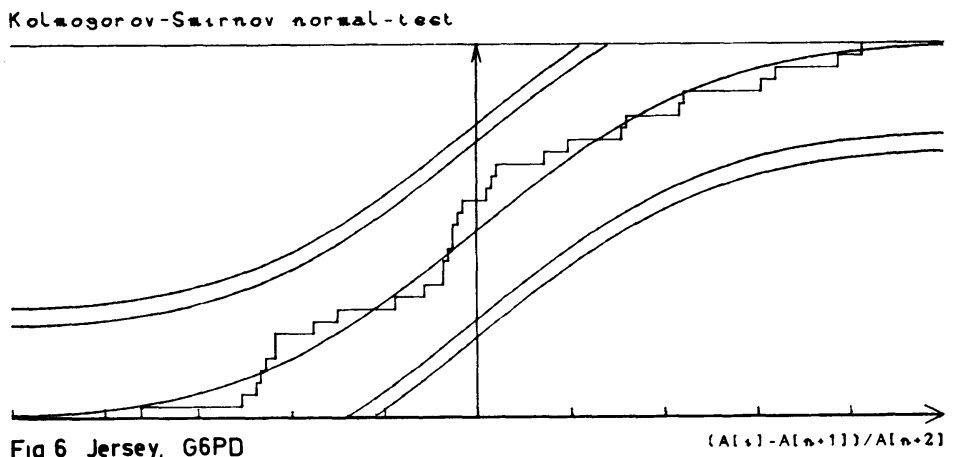

Fig 6 Jersey. G6PD

$(A[n)-A(n+1)) / A(n+2)$

Kolmogor ov-Smirnov normal-tect

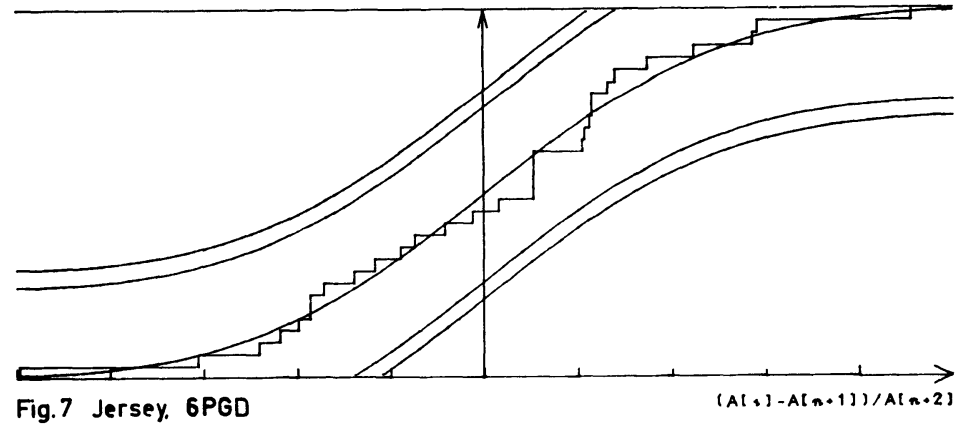


The major part of the calculations have been performed on a Gier digital computer at Århus University's Computing Centre. The program has been written by stud. oecon. Kai Wollf.

\section{RESULTS}

Activities of G6PD and 6PGD in the erythrocytes from cattle, older than 3 months

In the erythrocytes of 80 RDM cows, heifers, bulls and calves an average of $322 \pm 56$ units G6PD and $52.8 \pm 12.2$ units 6 PGD per $100 \mathrm{ml} \mathrm{PCV}$ were found; the number after the mean being the standard deviation. In a group of 46 similar SDM animals the activities were $330 \pm 43$ units G6PD and $47.1 \pm 9.2$ units 6PGD per $100 \mathrm{ml} \mathrm{PCV}$, and in 31 Jersey animals $315 \pm 39$ units G6PD and $49.2 \pm 8.0$ units $6 \mathrm{PGD}$ per $100 \mathrm{ml} \mathrm{PCV}$.

The observed activities of both enzymes were plotted on probability paper in order to assess the distribution of the enzyme activities in the three breeds. The distribution functions of G6PD were practically straight lines, but the distribution functions of 6PGD were delicately curved functions indicating a distribution with a certain skewness to the left of the 6PGD activities in all three breeds.

In order to gain a more detailed insight into the distribution of the activities of the two dehydrogenases, the compatibility of the observed and the normal distribution was tested by the Kolmogorov-Smirnov test $(11,25)$.

It can be seen from Figs. $2-7$ that the activities of both G6PD and 6PGD show a normal distribution in all three breeds. An F-test, however, shows that there are significant differences between the variances of the G6PD activities in RDM and SDM, and between RDM and Jersey. Moreover it is seen from Table 1 that the same characteristic differences between the breeds are also exhibited by the variances of the 6PGD activities. Further, Table 1 shows that according to the $t$-tests there is no significant difference between the mean activities of G6PD in the three breeds. There is, on the other hand, a significant difference between the mean activities of 6PGD in RDM and SDM, but not between RDM and Jersey. 
T a ble 1. Enzyme activities in bovine erythrocytes.

\begin{tabular}{|c|c|c|c|c|c|c|c|c|}
\hline Breed & $\mathbf{n}$ & $\begin{array}{l}\text { G6PD, units } \\
\text { per } 100 \mathrm{ml} \text { PCV }\end{array}$ & & F & $\mathbf{t}$ & $\begin{array}{l}\text { 6PGD, units } \\
\text { per } 100 \mathrm{ml} \text { PCV }\end{array}$ & $\mathrm{F}$ & $\mathbf{t}$ \\
\hline RDM & 80 & $322 \pm 56.1$ & $a b$ & $>$ & 一 & $52.8 \pm 12.2$ & $\gg$ & $\gg$ \\
\hline SDM & b 46 & $330 \pm 43.1$ & bc & - & 一 & $47.1 \pm 9.21$ & - & - \\
\hline Jersey & c 31 & $315 \pm 38.7$ & ac & $\gg$ & 一 & $49.2 \pm 8.03$ & $\gg$ & - \\
\hline All breeds & d 157 & $323 \pm 49.5$ & & & & $50.4 \pm 10.9$ & & \\
\hline Fetuses & e 29 & $766 \pm 136$ & de & $\gg$ & $\gg$ & $65.2 \pm 14.1$ & $\gg$ & $\gg$ \\
\hline Newborn & & & & & & & & \\
\hline calves & f 16 & $483 \pm 139$ & af & $\gg$ & $\gg$ & $75.5 \pm 20.8$ & $\gg$ & $\gg$ \\
\hline Man & g 10 & $274 \pm 51.4$ & & & & $194 \pm 38.0$ & & \\
\hline
\end{tabular}

means that the difference is significant at the 0.05 level, and $\gg$ at the 0.01 level. The human blood samples are collected from 9 men and 1 woman, aged between 20 and 30 years, and all normal and healthy.

T a b l e 2. Coefficients of correlation.

\begin{tabular}{|c|c|c|c|c|c|c|}
\hline & \multicolumn{2}{|c|}{ RDM } & \multicolumn{2}{|c|}{ SDM } & \multicolumn{2}{|c|}{ Jersey } \\
\hline & G6PD & 6PGD & G6PD & 6PGD & G6PD & 6PGD \\
\hline \multicolumn{7}{|c|}{ units per $100 \mathrm{ml} \mathrm{PCV}$} \\
\hline 6PGD'1) & 0.1973 & & 0.2082 & & 0.1330 & \\
\hline G6PD²) & $0.6742 \gg$ & & $0.8207 \gg$ & & $0.7352 \gg$ & \\
\hline 6PGD²) & 0.0299 & $0.8622 \gg$ & 0.0964 & $0.7448 \gg$ & -0.0341 & $0.8928 \gg$ \\
\hline MCHC & 0.3201 & 0.0425 & 0.1347 & 0.0523 & 0.3172 & -0.0849 \\
\hline Age & -0.1568 & 0.0082 & 0.1054 & 0.4151 & -0.2426 & -0.1162 \\
\hline \multicolumn{7}{|c|}{ units per $\mathrm{g} \mathbf{H b}$. } \\
\hline $\begin{array}{l}\text { MCHC r } \\
\text { MCHC b }\end{array}$ & $\begin{array}{l}-0.3941 \gg \\
-0.1558 \gg\end{array}$ & $\begin{array}{l}-0.4338 \gg \\
-0.0373 \gg\end{array}$ & $\begin{array}{l}-0.3178> \\
-0.1848>\end{array}$ & $\begin{array}{l}-0.2601> \\
-0.0448>\end{array}$ & $\begin{array}{l}-0.4047> \\
-0.1322>\end{array}$ & $\begin{array}{l}-0.5176 \gg \\
-0.0413 \gg\end{array}$ \\
\hline
\end{tabular}

The table shows the coefficient of correlation, $r$, except in the lower row, which gives the coefficient of regression, $b .>$ means that both the coefficient of correlation and of regression are significantly different from zero according to t-test and $\chi^{2}$ test for independency at the 0.05 level. $\gg$ means significant at the 0.01 level.

1) units per $100 \mathrm{ml} \mathrm{PCV.} \mathrm{2)} \mathrm{units} \mathrm{per} \mathrm{g} \mathrm{Hb}$. 
The age and milk yield of the animals

Investigations involving regression analysis and $\chi^{2}$ test for independency were made to see whether any covariance existed between the age of the animal and the activities of G6PD and 6PGD in the erythrocytes. Table 2 demonstrates the absence of any such covariance in any of the breeds.

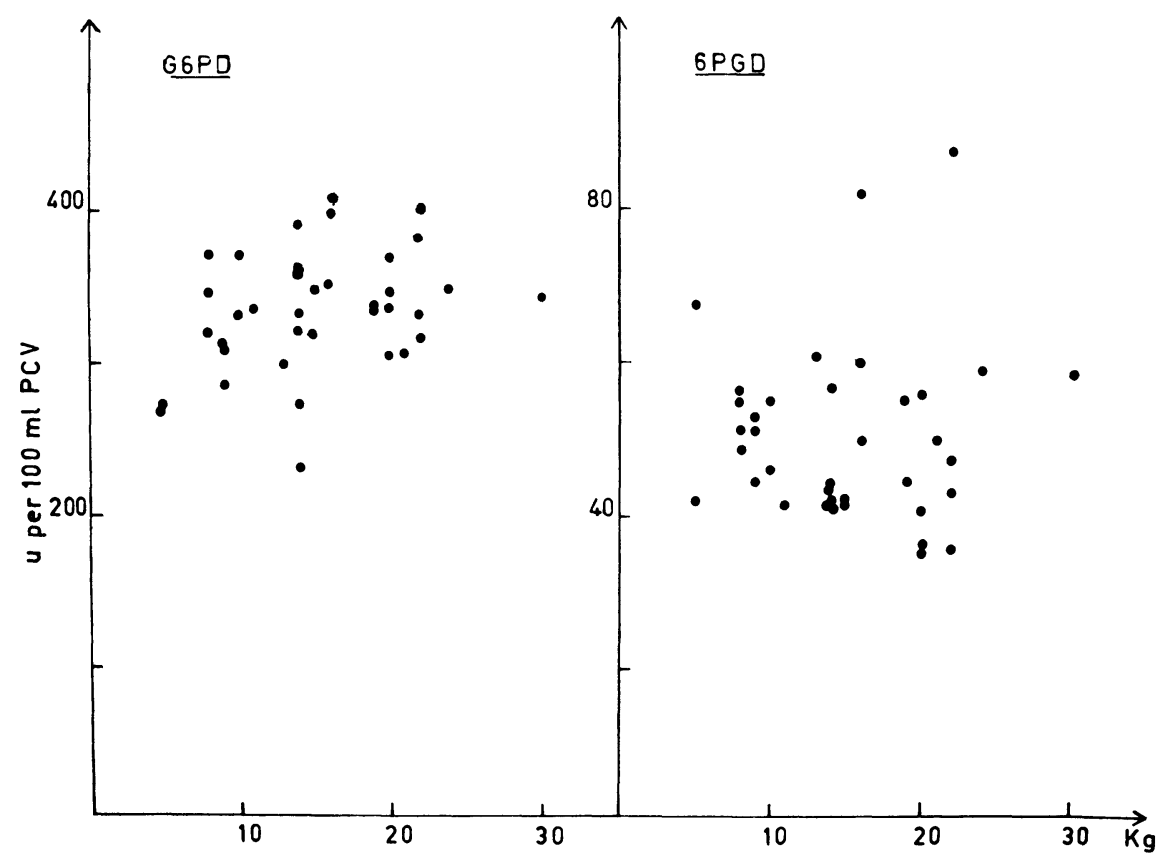

$\mathrm{Fig} \mathrm{u} \mathrm{r}$ e 8. The activities of G6PD and 6PGD in the erythrocytes of $\mathrm{RDM}, \mathrm{SDM}$ and Jersey cattle in relation to diurnal milk yield in $\mathrm{kg}$ milk.

Fig. 8 shows the activities of G6PD and 6PGD in the erythrocytes in relation to the milk yield of the same animals. As can be seen from Fig. 8 there is no significant covariance between the diurnal milk yield and enzyme activities.

Relation between activities of G6PD, 6PGD and MCHC

Statistical treatment of the results was carried out to see whether the activities of G6PD and 6PGD in the erythrocytes of the three breeds were correlated. The coefficients of correlation, as shown in Table 2, are not significantly different from zero for 
any of the breeds $(P>0.05)$, and a $\chi^{2}$ test for independency shows that the activities of the two enzymes are independent in all three breeds $(P>0.05)$. The table further indicates that neither the activity of G6PD nor the activity of 6PGD in the erythrocytes (in units per $100 \mathrm{ml} \mathrm{PCV}$ ) is correlated with the mean corpuscular hemoglobin concentration (MCHC).

The activities of G6PD and of 6PGD, which have been given in units per $100 \mathrm{ml} \mathrm{PCV}$, can be converted to units per gram hemoglobin by dividing units per $100 \mathrm{ml} \mathrm{PCV}$ with the MCHC of the corresponding suspension of erythrocytes. The converted mean activities are as follows: in RDM 9.68 \pm 1.77 units G6PD and $1.58 \pm 0.4$ units 6PGD per g Hb, in SDM $10.2 \pm 1.48$ units G6PD and $1.50 \pm 0.44$ units 6PGD per $\mathrm{g}$ Hb and in Jersey 8.66 \pm 1.08 units G6PD and $1.35 \pm 0.26$ units 6PGD per $\mathrm{g} \mathrm{Hb}$.

Regression analysis was carried out in order to investigate whether the activities of G6PD and 6PGD in units per $\mathrm{g} \mathrm{Hb}$ were correlated with MCHC. The coefficients of correlation are shown in Table 2. It can be seen that the activities of both G6PD and 6PGD show significant negative correlation to MCHC. In addition the coefficients of regression are significant at the $5 \%$ level for SDM and Jersey and at the $1 \%$ level for RDM.

The ratio between the 6PGD and G6PD activities is $0.17 \pm 0.03$ for RDM, $0.15 \pm 0.02$ for SDM and $0.16 \pm 0.02$ for Jersey.

G6PD and 6PGD activities in bovine fetal erythrocytes

In 29 fetuses of all breeds averages of $766 \pm 136$ units G6PD and $65.2 \pm 14.1$ units 6PGD per $100 \mathrm{ml} \mathrm{PCV}$ were found. Whereas the fetal G6PD activities are more than twice as high as in adult bovine erythrocytes, the fetal 6PGD activities are only slightly higher than in adult bovine erythrocytes. The difference between the 6PGD activities in fetal and adult erythrocytes is significant $(\mathrm{P}<0.01)$.

Fig. 9 shows the assessed age of the fetuses in relation to the activities of G6PD and 6PGD. The figure indicates that the enzyme activities are approximately constant during the embryonal period.

MCHC in fetuses $(28.4 \pm 4.1)$ is significantly lower than in mature cattle $(34.0 \pm 4.0)$. The $6 \mathrm{PGD} / \mathrm{G6PD}$ ratio in bovine fetal erythrocytes is $0.084 \pm 0.002$. 


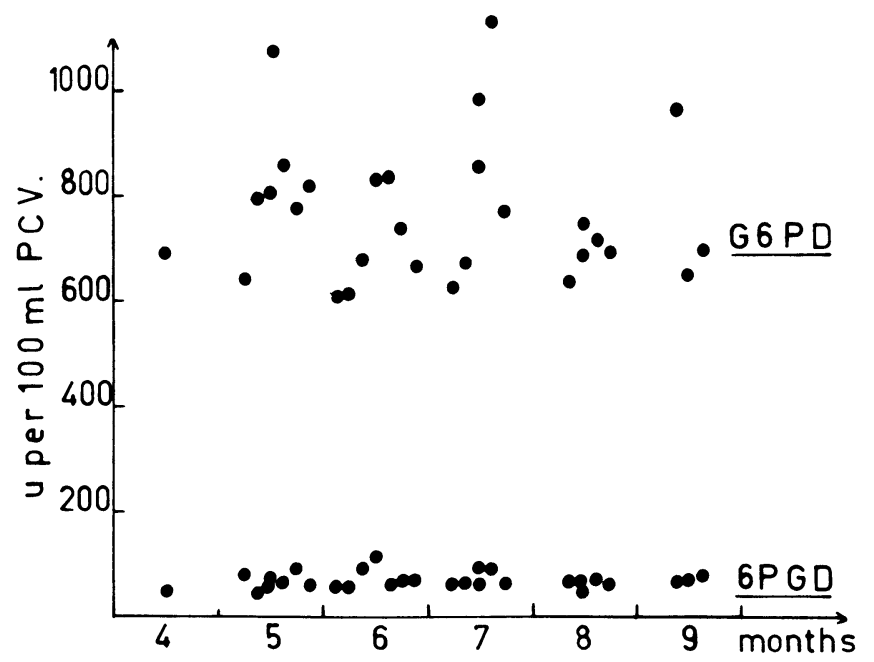

Figure 9. The activities of G6PD and 6PGD in the erythrocytes of 29 bovine fetuses in relation to the assessed age of the fetuses.

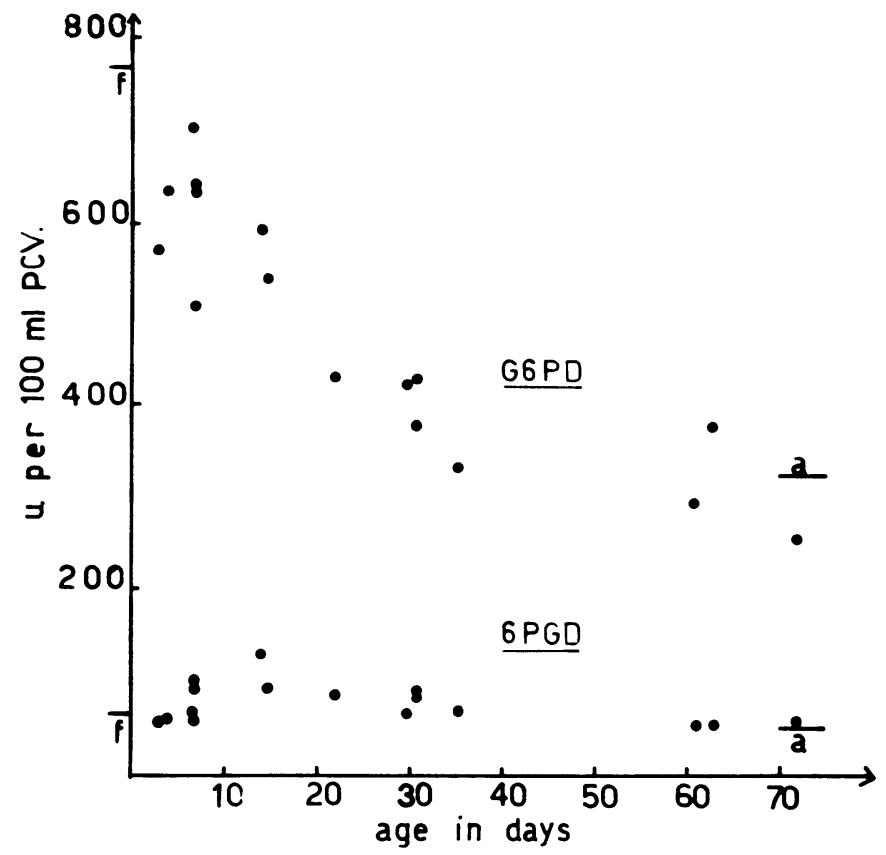

Figure 10 . The activities of G6PD and 6PGD in the erythrocytes of $\mathbf{1 6}$ newborn calves in relation to the age of the calves. $f$ and a denote the mean activities of G6PD and 6PGD in erythrocytes of fetuses and mature cattle respectively. The half period for the decrease in the G6PD activity is 34 days. 
The activities of G6PD and 6PGD in the erythrocytes of newborn calves

Determinations of the G6PD and 6PGD activities in erythrocytes of newborn calves gave the results shown in Fig. 10. The G6PD activities in one day old calves were of the same size as in fetuses, but decreased over a period of approximately 40 days to the mean activity in mature cattle. In the first days after the birth the 6PGD activity showed a tendency to increase, but subsequently decreased in the same way as the G6PD activity, reaching the mean activity approximately 40 days after birth.

The average glucose concentration in whole blood of the first 14 newborn calves was $89.4 \mathrm{mg} \%$, and the calves showed no signs of rumination.

\section{DISCUSSION}

G6PD and 6PGD activities in erythrocytes from mature cattle

The G6PD activity in bovine erythrocytes has not previously been investigated in a material comprising the cattle breeds common in Denmark. However, three studies on these enzymes in bovine erythrocytes of domestic breeds in other countries have been published.

Budtz-Olsen et al. (4) found G6PD activities in 6 cows (Australia), which were of approximately the same size as in normal human erythrocytes, and in any case higher than the G6PD activity in G6PD deficient human erythrocytes. Smith et al. (22) found 221 "units" per $\mathrm{g} \mathrm{Hb}$ in 4 cows (California) with an unspecified modification of the method of Glock \& McLean (8). Salvidio et al. (21) found in 19 cows (Italy) 7.1-7.3 "units" per g Hb. The "units", used by Salvidio et al. cannot be converted to the units used here, because Salvidio et al. did not quote the concentrations and volumes of the reagents in their methods. However, it can be calculated from their results that the mean activity in bovine erythrocytes corresponds to approximately $70 \%$ of the normal activity in human erythrocytes. The present investigations show that the G6PD activity in the erythrocytes of Danish cattle is of the same magnitude or higher than that in human erythrocytes.

The 6PGD activity in bovine erythrocytes has previously been determined only by Salvidio et al. (21), who, in a material consisting of 13 cows, found 1.6-1.8 "units" per $\mathrm{g} \mathrm{Hb}$, where the 
"unit" is the same as for G6PD, and "units" cannot be converted to the unit used in these investigations. According to Salvidio et al. (21) the 6PGD/G6PD ratio for bovine erythrocytes is approximately 0.24 , which is a little higher than the ratio 0.17 , found by the author. This difference is probably due to methodological differences, Salvidio et al. measured 6PGD activity at $\mathrm{pH} 9.0$, which is the $\mathrm{pH}$ optimum for 6PGD (8), while a $\mathrm{pH} 7.5$ is used here.

It is (vide Table 1) characteristic for bovine erythrocytes that the 6PGD activity is much lower than the G6PD activity. Such a low 6PGD activity in human erythrocytes would be pathological $(5,15,20)$. As shown in Table 1 the mean 6PGD activity in SDM is lower than in the other two breeds, and the 6PGD activity in RDM is higher than in SDM and Jersey. The difference between the mean 6PGD activities in SDM and RDM is significant. Further it is seen from Table 2 and Fig. 8 that the G6PD and 6PGD activities in cattle older than 3 months are independent of the age and milk yield of the animals.

\section{Relations between G6PD, 6PGD and $M C H C$}

The activities of G6PD and 6PGD are mutually independent, and the activities of both enzymes are independent of MCHC as long as the activities are measured in units per $100 \mathrm{ml}$ PCV. Many authors prefer, however, to measure the activities in units per $\mathrm{g} \mathrm{Hb}$. But as it has been shown that the activities of both G6PD and 6PGD in human erythrocytes decrease with increasing age of the single erythrocyte in vivo, and that concomitantly the hemoglobin concentration shows a relative elevation $(17,18)$, there are good reasons to expect that the activities of the two dehydrogenases in units per $\mathrm{g} \mathbf{H b}$ are correlated with MCHC. As seen from Table 2 there is, for all three breeds, a significant negative correlation between MCHC and G6PD and 6PGD activities respectively, when the activities are measured in units per $\mathrm{g} \mathrm{Hb}$, but not when the activities are measured in units per $100 \mathrm{ml} \mathrm{PCV}$. The negative correlation between the enzyme activities in units per $\mathrm{g} \mathrm{Hb}$ and MCHC may therefore reflect a certain variation in erythrocytic mean life span in the different blood samples. It seems justifiable to the author that the hemoglobin concentration in an erythrocyte suspension should not be used as parameter when measuring the G6PD and 6PGD activities, since the activities in this case will be correlated with their own parameter. 
G6PD and 6PGD in the erythrocytes of fetuses and newborn calves

In 29 bovine fetuses the G6PD activity was on the average 2.4 times and the 6PGD activity 1.3 times as high as in mature cattle. Comparably high fetal G6PD activities have been described in sheep $(10,14)$ and in man $(1,16)$. The high G6PD activities decrease in calves (vide Fig. 10) and in sheep (14) to the normal level for mature animals in just under 40 days. At present there is no explanation as to how the high G6PD activities in fetal erythrocytes can be explained. From investigations on the human erythrocyte it is known that the G6PD activity in newformed erythrocytes is higher than in older erythrocytes $(17,18)$, and that human fetal erythrocytes have a shorter life span than human adult erythrocytes (13). If this is also true for the bovine erythrocyte, the high G6PD activities in fetal erythrocytes could be due to an increased G6PD activity in newformed fetal erythrocytes and a shortened life span in the bovine fetal erythrocyte.

\section{ACKNOWLEDGMENTS}

I am indebted to Professor F. Schønheyder for his unfailing interest and help throughout this study, and to Mrs. Alice Nygaard for technical assistance.

\section{REFERENCES}

1. Bernard, S., J. C. Dubin, Y. Madec \& M. le Cam: Sur les variation de quelques activités enzymatiques dans le globule rouge humain, au cours de diverses circonstances physiologiques et pathologiques. Clin. chim. Acta 1966, 14, 300-310.

2. Beutler, Ernest: Glucose-6-phosphate dehydrogenase deficiency. In Stanbury, Wyngaarden and Frederickson (ed.): The Metabolic Basis of Inherited Disease, 2nd Ed. McGraw-Hill, 1965, 10, 1060-1089.

3. Bishop, Charles: Assay of glucose-6-phosphate dehydrogenase (E. C. 1.1.1.49) and 6-phosphogluconate dehydrogenase (E. C. 1. 1. 1. 43) in red cells. J. Lab. clin. Med. 1966, 68, $149-155$.

4. Budtz-Olsen, O. E., B. Axten \& S. Haigh: Glucose-6-phosphate dehydrogenase deficiency in erythrocytes of sheep and goats. Nature (Lond.) 1963, 198, 1102.

5. Carson, Paul E. \& H. Frischer: Glucose-6-phosphate dehydrogenase deficiency and related disorders of the pentose phosphate pathway. Amer. J. Med. 1966, 41, 744-761. 
6. Croxton, F. E.: Elementary statistics with applications in medicine and biological sciences. Dover Publications, Inc., New York 1953.

7. Dawson, R. M. C., D. C. Elliott, W. H. Elliott \& K. M. Jones: Data for biochemical research. Claredon Press, Oxford 1959, 51.

8. Glock, G. E. \& P. McLean: Further studies on the properties and assay of glucose-6-phosphate dehydrogenase and 6-phosphogluconate dehydrogenase of rat liver. Biochem. J. 1953, 55, $400-408$.

9. Hastings, C.: Approximations for digital computers. Princeton $1955,187$.

10. Herz, F., E. Kaplan \& E. J. Gleiman: Acetylcholinesterase and glucose-6-phosphate dehydrogenase activities in erythrocytes of fetal, newborn and adult sheep. Proc. Soc. exp. Biol. (N.Y.) 1967, 124, 1185-1187.

11. Hoel, Paul G.: Introduction to mathematical statistics. J. Wiley and Sons, Inc., New York 1962.

12. I.C.S.H.: Recommandations and requirements for haemoglobinometry in human blood. Scand. J. clin. Lab. Invest. 1965, 17, 617.

13. Kleihauer, Enno: Fetales Hämoglobin und fetale Erythrozyten. Ferdinand Enke, Stuttgart 1966.

14. Kronfeld, D. S., Fiora Raggi \& A. M. Frumin: Changing activity of erythrocyte glucose-6-phosphate dehydrogenase and tolerances to glucose and tolbutamide in growing sheep. Proc. Soc. exp. Biol. (N.Y.) 1967, 124, 1022-1025.

15. Löhr, G. W.: Glucose-stoffwechsel der Roten Blutzellen. Series Haematologica, 1965, 10, 1-22.

16. Löhr, G. \& H. Waller: Erythrozytenfermenten. Blutbildung und Blutumsatz beim Feten und Neugeborenen. Ed. R. Kepp und G. Oehlert. Ferdinand Enke, Stuttgart 1961, 119.

17. Marks, Paul A.: Glucose-6-phosphate dehydrogenase: Its properties and role in mature erythrocytes. In Bishop, C. \& D. M. Surgenor (ed.): The Red Blood Cell. Academic Press, New York 1964, 211-241.

18. Mortensen, Esper: Aldersforandringer af den normale humane erythrocyt. Diss. Århus 1965.

19. Nelson, Norton: A photometric adaption of the Somogyi method for the determination of glucose. J. biol. Chem. 1944, 153, $375-380$.

20. Parr, C. W. \& L. Fitch: Hereditary partial deficiency of human erythrocyte phosphogluconate dehydrogenase. Biochem. J. 1964, 93, 28c-30c.

21. Salvidio, E., I. Pannacciulli \& A. Tizianello: Glucose-6-phosphate and 6-phosphogluconic dehydrogenase activities in the red blood cells of several animal species. Nature (Lond.) 1963, $200,372-373$. 
22. Smith, J., J. K. Barnes, J. J. Kaneko \& R. A. Freedland: Erythrocytic enzymes of various animal species. Nature (Lond.) 1965, 205, 298-299.

23. Somogyi, M.: A new reagent for the determination of sugars. J. biol. Chem. 1945, 160, 61-68.

24. Somogyi, M.: Notes on sugar determination. J. biol. Chem. 1952, $195,19-23$.

25. Terp, S.: Personal communication. 1967.

26. Tholstrup, Niels: Glucose-6-fosfat dehydrogenase aktiviteten i erythrocyter ved tyreotoksikose. Ugeskr. Læg. 1966, 128, 919-924.

\section{SUMMARY}

The activities of glucose-6-phosphate dehydrogenase and of 6-phospho-gluconate dehydrogenase have been determined in cows, heifers, bulls and calves. The material consisted of 80 RDM, 46 SDM, 31 Jersey animals older than 3 months, 16 newborn RDM calves and 29 fetuses of various breeds.

a) In RDM averages of $322 \pm 56$ units G6PD and $52.8 \pm 12.2$ units 6PGD per $100 \mathrm{ml}$ PGV were found. In SDM $330 \pm 43$ units G6PD and 47.1 \pm 9.2 units 6PGD were found, and in Jersey $315 \pm 39$ units G6PD and $49.2 \pm 8.0$ units 6 PGD per $100 \mathrm{ml}$ PGV. The activities of both dehydrogenases were shown to be normally distributed in all three breeds.

b) The 6PGD activities in SDM were significantly lower than in RDM, but no other breed differences between the mean activities were detected.

c) There is no relation between the age (apart from fetuses and newborn calves), and milk yield of the animals and the activities of G6PD and 6PGD in the erythrocytes.

d) Statistical treatment of the results demonstrates that there is no relation between the G6PD and 6PGD activities in the blood samples, and that the enzyme activities in units per $100 \mathrm{ml} \mathrm{PCV}$ is not correlated with $\mathrm{MCHC}$.

e) Further, the statistical treatment shows that when measuring G6PD and 6PGD activities in erythrocytes, PCV is to be preferred to hemoglobin concentration as parameter.

f) In bovine fetuses G6DP activities more than twice as high as in adult erythrocytes were found, while the 6PGD activities were only slightly higher than in adult erythrocytes. After birth the high G6PD activities decreased over a period of 40 days to the normal level for mature cattle. The 6PGD activity also attains the normal level for older animals in approximately 40 days after birth. 


\section{ZUSAMMENFASSUNG}

Die normalen Aktivitäten der Glucose-6-Phosphat-Dehydrogenase und der 6-Phosphogluconat-Dehydrogenase in Erythrozyten des Rindes.

Die Aktivitäten der Glucose-6-Phosphat-Dehydrogenase (G6PD) und die der 6-Phosphogluconat-Dehydrogenase (6PGD) in den Erythrozyten sind auf Grundlage eines Materials bestimmt, das aus 80 Kühen, Färsen, Stieren und Kälbern aus der Roten Dänischen Milchviehrasse (RDM), 46 Individuen aus der Schwarzbunten Dänischen Milchviehrasse (SDM), 31 Individuen aus der Jerseyrasse, 16 neugeborenen Kälbern und 29 Kälberfötussen besteht.

a) Bei der RDM wurden $322 \pm 56$ Einheiten G6PD und 52,8 $\pm 12,2$ Einheiten 6PGD pro $100 \mathrm{ml}$ PGV gefunden. Bei der SDM wurden $330 \pm$ 43 Einheiten G6PD und 47,1 \pm 9,2 Einheiten 6PGD pro $100 \mathrm{ml}$ PGV gefunden, und bei der Jerseyrasse $315 \pm 39$ Einheiten G6PD und 49,2 \pm 8,0 Einheiten 6PGD pro $100 \mathrm{ml}$ PGV. Die statistische Behandlung zeigt, dass die Aktivitäten der beiden Fermente bei allen Rassen normal verteilt sind.

b) Die Differenz zwischen den Aktivitäten der 6PGD bei der SDM und bei der RDM ist signifikant, aber es gibt übrigens keine signifikanten Differenzen zwischen den durchschnittlichen G6PD- und 6PGDAktivitäten der Rassen.

c) Es besteht keine Kovarianz zwischen dem Alter (von Fötussen und neugeborenen Kälbern abgesehen), der Milchleistung der Tiere und den Aktivitäten der G6PD und der 6PGD in den Erythrozyten.

d) Aus statistischen Untersuchungen geht hervor, dass es in den einzelnen Biutproben keine Korrelation zwischen den Aktivitäten der G6PD und denen der 6PGD gibt, und dass die Aktivitäten der Fermente nicht mit der MCHC korreliert sind.

e) Die statistische Untersuchung ergibt ferner, dass das PGV bei Angabe der Aktivitäten der G6PD und der 6PGD in den Erythrozyten als Parameter der Hämoglobinkonzentration vorzuziehen ist.

f) Bei den Kälberfötussen finden sich G6PD-Aktivitäten, die mehr als doppelt so gross wie die durchschnittlichen Aktivitäten bei erwachsenen Tieren sind, während die 6PGD-Aktivitäten bei Fötussen nur wenig erhöht sind. Bei neugeborenen Kälbern ist die Aktivität der G6PD unmittelbar nach der Geburt von derselben Grösse wie bei Fötussen. Die Aktivität der G6PD bei neugeborenen Kälbern sinkt im Laufe von etwa 40 Tagen bis zu der normalen Aktivität bei erwachsenen Tieren. Die Aktivität der 6PGD bei neugeborenen Kälbern erreicht ebenfalls innerhalb etwa 40 Tagen die normale 6PGD-Aktivität.

\section{SAMMENDRAG}

De normale aktiviteter af glucose-6-phosphat dehydrogenase og 6-phospho-gluconat dehydrogenase $i$ bovine erythrocyter.

Aktiviteterne af glucose-6-phosphat dehydrogenase og af 6-phospho-gluconat dehydrogenase $i$ erythrocyterne er bestemt på et materiale bestående af $80 \mathrm{k} \emptyset \mathrm{er}$, kvier, tyre og kalve af RDM, 46 af SDM, 31 af jerseyrace, 16 spædkalve og 29 fostre. 
a) Hos RDM fandtes $322 \pm 56$ enheder G6PD og 52,8 $\pm 12,2$ enheder 6PGD pr. $100 \mathrm{ml}$ PCV. Hos SDM fandtes $330 \pm 43$ enheder G6PD og 47,1 $\pm 9,2$ enheder 6PGD pr. $100 \mathrm{ml} \mathrm{PCV} \mathrm{og} \mathrm{hos} \mathrm{jersey} 315 \pm 39$ enheder G6PD og 49,2 $\pm 8,0$ enheder 6PGD pr. $100 \mathrm{ml}$ PGV. Aktiviteterne af begge enzymer er normalt fordelt hos alle racer.

b) 6PGD aktiviteterne hos SDM er signifikant lavere end hos RDM, men der er i $\emptyset$ vrigt ikke signifikante forskelle mellem racernes gennemsnitlige G6PD- og 6PGD-aktiviteter.

c) Der er ingen relation mellem dyrenes alder (bortset fra fostre og spæde kalve), ydelse og aktiviteterne af G6PD og 6PGD i erythrocyterne.

d) Statistiske unders $\varnothing$ gelser viser, at der ikke er korrelation mellem G6PD og 6PGD aktiviteterne i de enkelte blodprøver, og at enzymaktiviteterne ikke er korreleret med MCHC.

e) Den statistiske behandling af resultaterne viser endvidere, at ved angivelse af G6PD og 6PGD aktivitet i erythrocyterne b $\phi r$ PCV foretrækkes frem for hæmoglobinkoncentrationen som parameter.

f) Hos kalvefostre findes G6PD aktiviteter på mere end det dobbelte af gennemsnitsaktiviteterne hos ældre dyr, medens 6PGD aktiviteterne kun er lidt forhøjede. Hos spæde kalve er G6PD aktiviteten lige efter fødslen af samme størrelse som hos fostre. G6PD aktiviteten hos spæde kalve falder i løbet af ca. 40 dage til den normale aktivitet for ældre dyr. 6PGD aktiviteten hos spæde kalve falder ligeledes til den normale 6PGD aktıvitet i løbet af ca. 40 dage.

(Received March 29, 1968). 